\title{
Ectopic pregnancy: a diagnostic dilemma
}

\author{
Saha Pradip Kumar*, Gupta Pratiksha², Goel Poonam², Sehgal Alka², Huria Anju², \\ Shailja Kataria ${ }^{2}$, Rimpy Tandon ${ }^{2}$
}

\author{
${ }^{1}$ Department of Obstetrics and Gynecology, Postgraduate Institute of Medical Education and Research, Chandigarh, \\ India \\ ${ }^{2}$ Department of Obstetrics and Gynecology, Government Medical College \& Hospital, Chandigarh 160012, India
}

Received: 23 November 2015

Accepted: 08 January 2016

\section{*Correspondence:}

Dr. Saha Pradip Kumar,

E-mail: pradiplekha@yahoo.co.in

Copyright: (C) the author(s), publisher and licensee Medip Academy. This is an open-access article distributed under the terms of the Creative Commons Attribution Non-Commercial License, which permits unrestricted non-commercial use, distribution, and reproduction in any medium, provided the original work is properly cited.

\begin{abstract}
Background: To study the etiology, varied clinical presentations and misdiagnosis in ectopic pregnancy.

Methods: A retrospective analysis of all operated ectopic pregnancies over a 7 year period at Government Medical College \& hospital, Chandigarh was done. Details of clinical findings and misdiagnosis were noted. Surgically confirmed cases were included in this study. Expectant management and Medical management cases were excluded in this study.

Results: Two hundred eighty two cases of ectopic gestation were analyzed. Identifiable risk factor present in 221 cases $(78.3 \%)$. Pain was the commonest presenting symptom and 78 cases $(27 \%)$ were misdiagnosed before the correct diagnosis was made by our department.

Conclusions: Ectopic pregnancy can have varied presentations and misdiagnosis can be seen in Surgical, Medical and Gynaecology Departments. A young female with amenorrhea, pain abdomen with or without vaginal bleeding in early pregnancy diagnosis of ectopic pregnancy must be kept in mind. Early diagnosis would help early intervention and thus reduce the morbidity.
\end{abstract}

Keywords: Ectopic pregnancy, Misdiagnosis

\section{INTRODUCTION}

Over the last few decades, the incidence of ectopic pregnancy has increased almost to the extent of an epidemic disease. Ectopic pregnancy is one of the commonest acute abdominal emergencies. ${ }^{1,2}$ The risk of death from an ectopic pregnancy is 10 times greater than that for an induced abortion. ${ }^{3}$ Clinical manifestations may be diverse and diagnosis of this condition is often mistaken and delayed leading to increased morbidity and even mortality in these patients. We present an analysis of all cases of ectopic pregnancy surgically managed at our hospital over a period of seven years with the aim to see the risk factor for ectopic pregnancy, clinical presentations and diagnostic difficulties in 282 ectopic pregnancies.

\section{METHODS}

Detailed retrospective analysis of all the patients diagnosed to have ectopic pregnancy over a period of seven years was made. A total of 282 patients were managed surgically in the department of Obstetrics \& Gynaecology of Government Medical College \& Hospital, Chandigarh from April 1998 to April 2005.

Primary outcome measured in this study was to find out percentage of misdiagnosis of ectopic pregnancy as it is commonly occurred and whether misdiagnosis were more prevalent if the patient report to the doctor other than Gynaecologist.

Secondary outcome was to find out clinical findings, presenting symptom, risk factors for ectopic pregnancy. 
Patients presenting in Medical and surgical departments with different diagnosis were noted.

Diagnosis was made by urine pregnancy test and Ultrasound. Surgically confirmed cases were included in this study. Expectant management and Medical management cases were excluded in this study.

\section{RESULTS}

Two hundred eighty two cases of ectopic gestation were analyzed during a period of seven years. It was a retrospective study conducted in a university teaching hospital (Government Medical College \& Hospital, Chandigarh). A detailed note was made of the past, obstetric, menstrual and medical history. Emphasis was laid on any previous health check up and the diagnosis made at that centre before reaching our institute. Presenting symptoms, pelvic examination and operative findings were noted.

Maximum number of the patients was in the age group of $26-30$ years $(32.62 \%)$ but the age ranged between $20-45$ years (Table 1).

Table 1: Ectopic pregnancy in relation to age of patient.

\begin{tabular}{|lll|}
\hline Age in years & No. of cases & $\%$ age \\
\hline$<20$ & 31 & $10.99 \%$ \\
\hline$<21-25$ & 85 & $30.14 \%$ \\
\hline $26-30$ & 92 & $32.62 \%$ \\
\hline $31-35$ & 53 & $18.79 \%$ \\
\hline $36-40$ & 12 & $4.20 \%$ \\
\hline$>40$ years & 09 & $3.19 \%$ \\
\hline
\end{tabular}

Identifiable risk factors like previous history of tubal ligation, induced or spontaneous abortion, intrauterine contraceptive device use, pelvic inflammatory disease, history of infertility, previous ectopic pregnancy, previous abdominopelvic surgery and pelvic tuberculosis were seen in 221 cases viz. $78.37 \%$ (Table 2).

Misdiagnosis and delayed diagnosis was seen in 78 cases (27.58\%). These patients were seen once or twice by a doctor before the correct diagnosis was made in our department. These patients presented in different departments like Medicine and Surgery with varied complaints.

Out of the 282 cases analyzed, $231(81.91 \%)$ presented in Gynaecology OPD and emergency department, 38 $(13.47 \%)$ in Surgery and $13(4.60 \%)$ in Medicine. Of the 38 cases presenting in the Surgery department, 31 were misdiagnosed as appendicitis, urinary tract infection, cholecystitis, ureteric or renal colic, peritonitis, intestinal obstruction, colitis, pancreatitis etc. In patients presenting in medicine emergency all the 13 were misdiagnosed as gastroenteritis gastritis, pancreatitis etc. (Table $3 \& 4$ ).
Table 2: Risk factors in patients of ectopic pregnancy.

\begin{tabular}{|lll|}
\hline Risk factors & $\begin{array}{l}\text { No. of } \\
\text { patients }\end{array}$ & \% age \\
\hline No. identifiable risk factors & 61 & $21.63 \%$ \\
\hline Tubal ligation & 17 & $6.2 \%$ \\
\hline $\begin{array}{l}\text { Intrauterine contraceptive } \\
\text { device }\end{array}$ & 31 & $10.99 \%$ \\
\hline H/o Infertility & 62 & $21.98 \%$ \\
\hline $\begin{array}{l}\text { H/o previous abortion } \\
\begin{array}{l}\text { Spontaneous } \\
\text { Induced }\end{array}\end{array}$ & 84 & $29.78 \%$ \\
\hline $\begin{array}{l}\text { Previous abdomino-pelvic } \\
\text { surgery }\end{array}$ & 32 & $11.34 \%$ \\
\hline $\begin{array}{l}\text { H/o Pelvic inflammatory } \\
\text { disease / Tuberculosis }\end{array}$ & 08 & $18.43 \%$ \\
\hline Previous ectopic pregnancy & 04 & $11.70 \%$ \\
\hline ART & 01 & $0.35 \%$ \\
\hline Multiple Risk factors & 34 & $12.5 \%$ \\
\hline
\end{tabular}

Table 3: Patients presenting in medical and surgical departments with different diagnosis.

\begin{tabular}{|lll|}
\hline Department & $\begin{array}{l}\text { Total number } \\
\text { of patients }\end{array}$ & Percentages \\
\hline Medicine & 13 & $4.6 \%$ \\
\hline Gastroenteritis & 08 & $2.83 \%$ \\
\hline Gastritis & 02 & $0.70 \%$ \\
\hline Pain abdomen & 02 & $0.70 \%$ \\
\hline Pancreatitis & 01 & $0.35 \%$ \\
\hline $\begin{array}{l}\text { Surgery } \\
\text { Department }\end{array}$ & 38 & $13.47 \%$ \\
\hline $\begin{array}{l}\text { Ectopic } \\
\text { pregnancy }\end{array}$ & 07 & $2.48 \%$ \\
\hline Appendicitis & 07 & $2.48 \%$ \\
\hline $\begin{array}{l}\text { Urinary tract } \\
\text { infection }\end{array}$ & 02 & $0.70 \%$ \\
\hline Pain abdomen & 03 & $1.06 \%$ \\
\hline Pancreatitis & 01 & $0.35 \%$ \\
\hline Cholecystitis & 04 & $1.41 \%$ \\
\hline $\begin{array}{l}\text { Ureteric / renal } \\
\text { colic }\end{array}$ & 04 & $1.41 \%$ \\
\hline Colitis & 03 & $1.06 \%$ \\
\hline $\begin{array}{l}\text { Internal } \\
\text { obstruction }\end{array}$ & 03 & $1.06 \%$ \\
\hline Peritonitis & 04 & $1.41 \%$ \\
\hline
\end{tabular}

Out of the 231 cases presented to the Gynecology Department $69(24.46 \%)$ patients were referred to our institute.

Urine for pregnancy test was positive in all cases except two who had chronic ectopic pregnancy.

Out of these 69 referred patients $35(12.41 \%)$ were sent with the correct diagnosis whereas in 34 cases misdiagnosis were made in the form of threatened abortion, incomplete abortion, complete abortion, missed 
abortion, appendicitis, peritonitis, pelvic inflammatory disease, urinary tract infection, dysfunctional uterine bleeding and placenta praevia (Table 4).

Table 4: Patients presenting in Gynecology departments with different diagnosis.

\begin{tabular}{|lll|}
\hline $\begin{array}{l}\text { Gynecology } \\
\text { departments }\end{array}$ & $\begin{array}{l}\text { No. of } \\
\text { patients }\end{array}$ & $\%$ age \\
\hline Total No. of cases & 231 & $81.91 \%$ \\
\hline a) Direct & 162 & $57.03 \%$ \\
\hline b) Referred & 69 & $24.46 \%$ \\
\hline i) Ectopic pregnancy & 35 & $12.41 \%$ \\
\hline ii $)$ Misdiagnosis & 34 & $12.05 \%$ \\
\hline a) Threatened & 12 & $4.25 \%$ \\
\hline b) Incomplete & 07 & $2.48 \%$ \\
\hline c) PID & 05 & $1.7 \%$ \\
\hline d) Peritonitis & 02 & $0.70 \%$ \\
\hline e) Urinary Tract & 02 & $0.70 \%$ \\
Infection & & \\
\hline f) Appendicitis & 02 & $0.70 \%$ \\
\hline g) Placenta praevia & 01 & $0.35 \%$ \\
\hline h) Complete abortion & 01 & $0.35 \%$ \\
\hline i) Dysfunctional & 01 & $0.35 \%$ \\
\hline Uterine Bleeding & & \\
\hline j) Missed abortion & 01 & $0.35 \%$ \\
\hline
\end{tabular}

As far as symptomatology were concerned Pain was the commonest presenting symptom $(92.90 \%)$ followed by amenorrhoea $(78.72 \%)$ and irregular vaginal bleeding in $71.98 \%$ cases. Nausea and vomiting were seen in $53 \%$ cases. Syncopal attacks were seen in $40 \%$ patients. Abdominal tenderness was seen in $53.90 \%$ patients followed by vaginal tenderness in $57.80 \%$ cases, $46.80 \%$ had an adnexal mass, $9.92 \%$ cases came in shock (Table 5).

Table 5: Patients presented with different clinical features.

\begin{tabular}{|lll|}
\hline Symptoms & No. of patients & $\%$ age \\
\hline Amenorrhoea & 222 & $78.72 \%$ \\
\hline Pain abdomen & 262 & $92.90 \%$ \\
\hline Bleeding & 203 & $71.98 \%$ \\
\hline Vomiting & 141 & $50 \%$ \\
\hline Fainting attack & 115 & $40.78 \%$ \\
\hline Signs & \\
\hline Adnexal mass & 132 & $46.80 \%$ \\
\hline Cervical excitation & 163 & $57.80 \%$ \\
\hline Abdominal findings & 152 & $53.90 \%$ \\
\hline Shock & 28 & $9.92 \%$ \\
\hline
\end{tabular}

\section{DISCUSSION}

Ectopic pregnancy is an increasingly common and potentially catastrophic condition. Misdiagnosis of ectopic pregnancy is quite common .Delayed diagnosis may endanger the life of the patient but also decreases later the likelihood of a future successful pregnancy. ${ }^{4}$

There are a very few other disorders in obstetrics that has so many different presentations. The presentation of the patient may vary, some with minimal symptoms to a patient in a state of shock with massive haemoperitoneum. Some may present as a case of mass abdomen as in chronic ectopic. Vasomotor symptoms causing vertigo and syncope may be the presenting complaint. $^{3,4}$

Brenner and associate in 1980 reported that of 300 women with ectopic pregnancy, approximately $1 / 3$ had been seen once and $11 \%$ twice before the correct diagnosis was made. ${ }^{5}$ Same was the experience with us. Twenty seven percent had been seen earlier and were misdiagnosed before the correct diagnosis was made. In spite of all available modern diagnostic facilities diagnosis was missed in $78(27 \%)$ cases of which 34 were missed by gynecologist seen outside. There are more chances of misdiagnosis if the patient presents to the department other than Gynecology \& Obstetrics. There should be a high index of suspicion for this condition in patients of reproductive age group presenting with pain and irregular bleeding per vagina. History of amenorrhea may not be there in $20-25 \%$ of the cases as was seen in our study also. For the above reasons the patient may not always come to a Gynecologists, she may visit a physician or a general surgeon as the symptoms are so varied.

Common causes of ectopic pregnancy in our study were previous history of abortion and infertility but there could be no identifiable risk factor in $21 \%$ of cases. These findings are also similar with the study done by Ankum et al. $^{6}$

\section{CONCLUSIONS}

Misdiagnosis of ectopic pregnancy is very frequent especially if the patient present in any department other than Gynecology leading to delay in diagnosis.

A young female with amenorrhea and pain abdomen with or without vaginal bleeding comes in emergency Department diagnosis of ectopic pregnancy must be kept in mind.

High index of suspicion and a simple urine pregnancy test (ELISA) and if facilities are available, a transvaginal ultrasound can diagnose most of the cases. Early diagnosis would help early intervention and thus reduce the morbidity.

\section{Funding: No funding sources \\ Conflict of interest: None declared}

Ethical approval: The study was approved by the Institutional Ethics Committee 


\section{REFERENCES}

1. Challoner $\mathrm{K}$, Incerpi $\mathrm{M}$. Non traumatic abdomino surgical emergencies in the pregnant patients. Emerg Med Clin North Am. 2003;21(4):971-85.

2. Maymon R, Shulman A, Maymon BB, Bar-Levy F, Lotan M, Bahary C. Ectopic pregnancy, the new gynaecological epidemic disease: review of the modern work up and the non surgical treatment option. Int J fertile. 1992:37(3):146-64.

3. Dorfman SF. Deaths from ectopic pregnancy, United States 1979 to 1980. Obstet Gynecol. 1983;62:344.

4. Jones EE. Ectopic pregnancy: Common and some uncommon misdiagnosis. Obstet Gynecol Clin North Am. 1991;18:55-72.
5. Brenner PF, Ray S, Mishell DR. Ectopic pregnancy: A study of 300 conservative surgically treated cases. JAMA. 1980;243-673.

6. Ankum WM, Mol BW, Van der Veen F, Bossuyt PM. Risk factors for ectopic pregnancy: a metaanalysis. Fertil Steril. 1996;65(6):1093-9.

Cite this article as: Saha PK, Gupta $\mathrm{P}$, Goel $\mathrm{P}$, Sehgal A, Huria A, Kataria S, Tandon R. Ectopic pregnancy: a diagnostic dilemma. Int J Reprod Contracept Obstet Gynecol 2016;5:367-70. 